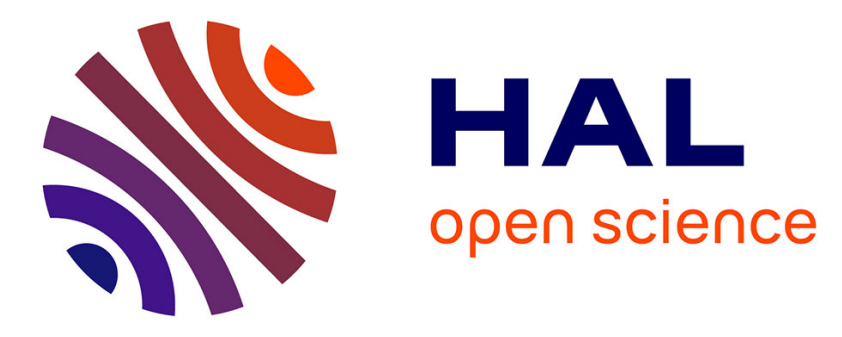

\title{
The stepwise oxidation of indolino[2,1-b]oxazolidine derivatives
}

Rachid Hadji, György Szalóki, Olivier Alévêque, Eric Levillain, Lionel Sanguinet

\section{- To cite this version:}

Rachid Hadji, György Szalóki, Olivier Alévêque, Eric Levillain, Lionel Sanguinet. The stepwise oxidation of indolino[2,1-b]oxazolidine derivatives. Journal of Electroanalytical Chemistry, 2015, 749, pp.1-9. 10.1016/j.jelechem.2015.04.032 . hal-01390948

\section{HAL Id: hal-01390948 \\ https://hal.science/hal-01390948}

Submitted on 20 Feb 2020

HAL is a multi-disciplinary open access archive for the deposit and dissemination of scientific research documents, whether they are published or not. The documents may come from teaching and research institutions in France or abroad, or from public or private research centers.
L'archive ouverte pluridisciplinaire $\mathbf{H A L}$, est destinée au dépôt et à la diffusion de documents scientifiques de niveau recherche, publiés ou non, émanant des établissements d'enseignement et de recherche français ou étrangers, des laboratoires publics ou privés. 


\section{Accepted Manuscript}

The stepwise oxidation of indolino[2,1-b]oxazolidine derivatives

Rachid Hadji, György Szalóki, Olivier Alévêque, Eric Levillain, Lionel

Sanguinet

PII:

S1572-6657(15)00203-9

DOI:

http://dx.doi.org/10.1016/j.jelechem.2015.04.032

Reference:

JEAC 2097

To appear in:

Journal of Electroanalytical Chemistry

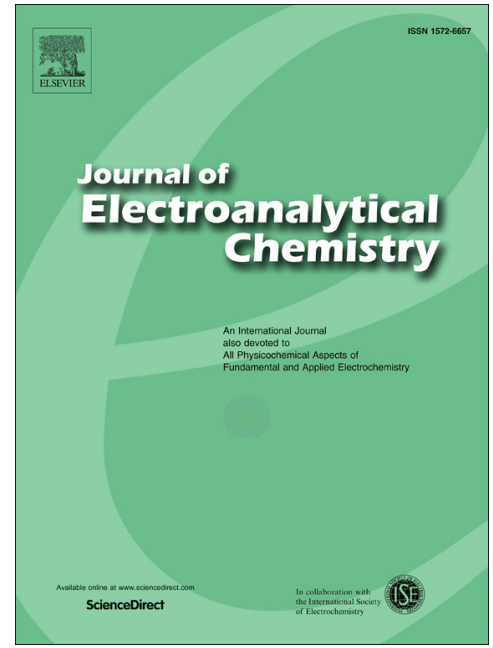

Received Date: 27 March 2015

Revised Date: $\quad 18$ April 2015

Accepted Date: $\quad 23$ April 2015

Please cite this article as: R. Hadji, G. Szalóki, O. Alévêque, E. Levillain, L. Sanguinet, The stepwise oxidation of indolino[2,1-b]oxazolidine derivatives, Journal of Electroanalytical Chemistry (2015), doi: http://dx.doi.org/ 10.1016/j.jelechem.2015.04.032

This is a PDF file of an unedited manuscript that has been accepted for publication. As a service to our customers we are providing this early version of the manuscript. The manuscript will undergo copyediting, typesetting, and review of the resulting proof before it is published in its final form. Please note that during the production process errors may be discovered which could affect the content, and all legal disclaimers that apply to the journal pertain. 
The stepwise oxidation of indolino[2,1-b]oxazolidine derivatives.

Rachid Hadji, György Szalóki, Olivier Alévêque*, Eric Levillain and Lionel Sanguinet.

Université d'Angers, CNRS UMR 6200, Laboratoire MOLTECH-Anjou, 2 bd Lavoisier, 49045 ANGERS cedex, France.

* Corresponding authors: Tel.: (+33)241735090; Fax: (+33)241735405

E-mail address: olivier.aleveque@univ-angers.fr (Olivier Alévêque)

\begin{tabular}{|c|c|}
\hline ARTICLE INFO & ABSTRACT \\
\hline $\begin{array}{l}\text { Keywords: } \\
\text { indolino[2,1-b]oxazolidine } \\
\text { Multi-responsive systems } \\
\text { Cyclic voltammetry } \\
\text { Spectroelectrochemistry } \\
\text { Electrochemical simulations }\end{array}$ & $\begin{array}{l}\text { This work presents an original strategy to modulate the electrochemical } \\
\text { properties of the indolino[2,1-b]oxazolidine core appropriately substituted } \\
\text { in position } 5 \text { (para-substitution of the phenyl ring) by acceptor or donor } \\
\text { groups ( } \mathrm{CHO}, \mathrm{OMe}, \mathrm{Me}, \mathrm{F}, \mathrm{H}, \mathrm{Cl}, \mathrm{Br} \text { ). Supported by } \\
\text { spectroelectrochemical experiments and confronted to electrochemical } \\
\text { simulations, the stepwise oxidation of indolino[2,1-b]oxazolidine } \\
\text { derivatives involves an electrochemical mechanism which depends on } \\
\text { the para-substitution of the phenyl ring and leads to either the formation } \\
\text { of a stable radical cation, the opening of the oxazolidine ring or an } \\
\text { irreversible aryl C-C coupling. }\end{array}$ \\
\hline
\end{tabular}

\section{Introduction}

Multi-responsive systems have attracted a lot of interest since several years, due to their promising applications in the field of molecular logic gates [1]. These systems can be defined as molecular systems which exist under several forms presenting different properties which can be interconverted by using different external stimuli such as light, heat, chemical species, proton or electron [2]. In this context, numerous molecules, involving the combination of several molecular switches connected by covalent links, were designed in order to modulate their optical, photophysical, redox, or complexation behaviours [3]. Indolino[2,1-b]oxazolidine derivatives (BoX) are a recent family of photochromic dyes $[4,5]$ and associated with various styrylic residues could act as a switch displaying photo-, acido- and recently electrochromic performances [6]. Indeed, the opening of the oxazolidine ring could be reversibly and selectively achieved either under UV irradiation, acidity changes or electro-oxidation, and conduct to the corresponding indoleninium [7].

If numerous studies report the electrochromic properties and electrochemical behavior of the spiropyranes which represent a Box analogue [8], to the best of our knowledge, and despite a real potential for electrochemical applications, only few works have been devoted to the specific design and fine electrochemical characterisations of indolino[2,1-b]oxazolidine derivatives [9]. This conclusion is also true for the indolino[2,1-b]oxazolidine core, that has not been extensively studied despite numerous options to introduce some chemical modifications either on indoline moiety itself or on pendant pi conjugated system, and that could modulate its properties. 
In light of this situation, we propose to synthetize different indolino[2,1-b]oxazolidine derivatives appropriately substituted in position 5 (para substitution of the phenyl ring - Scheme 1) by different acceptor or donor groups ( $\mathrm{CHO}, \mathrm{OMe}, \mathrm{Me}, \mathrm{F}, \mathrm{H}, \mathrm{Cl}, \mathrm{Br}$ ) in order to study, by electrochemistry spectroelectrochemistry and electrochemical simulations the influence of these para substituents on redox properties.

\section{Experimental section}

\subsection{Chemicals}

General Experimental Conditions:

For purifications, technical grade silica gel (Aldrich, pore size $60 \AA$, 230-400 mesh, 40-63 $\mu \mathrm{m}$ ) was used. For flash column chromatography, crystallizations and additional manipulations technical grade, non-dry solvents were used. Characterization of the isolated products was carried out in $\mathrm{CDCl}_{3}$ or $\left(\mathrm{CD}_{3}\right)_{2} \mathrm{SO}$ at $25{ }^{\circ} \mathrm{C}$. Chemical shifts are reported in ppm relative to the solvent residual value: $\delta=7.26\left(\mathrm{CDCl}_{3}\right), 2.50\left(\left(\mathrm{CD}_{3}\right)_{2} \mathrm{SO}\right)$ for ${ }^{1} \mathrm{H}$ NMR and $\delta=77.16\left(\mathrm{CDCl}_{3}\right), 39.52\left(\left(\mathrm{CD}_{3}\right)_{2} \mathrm{SO}\right)$ for ${ }^{13} \mathrm{C}$ NMR. Coupling constants are reported in $\mathrm{Hz}$ and rounded to the nearest $0.1 \mathrm{~Hz}$. Where necessary, DEPT, HMQC, COSY, HMBC, experiments were carried out to aid assignments.

Synthesis of indolinooxazolidines BoX-H,[7] BoX-F,[10] BoX-Cl,[10] BoX-Br,[11] BoX-Me,[8] BoX-CHO,[11] BoX-OMe [12] has already been described, therefore will not be discussed here.

\section{Synthesis of 5-Bis-(2,3,3-trimethylindolino[1,2-b]oxazoline) i.e (BoX-BoX):}

To a solution of 5-Bromo-2,3,3-trimethylindolino[1,2-b]oxazoline $(0.25 \mathrm{~g}, 0.89 \mathrm{mmol})$ in THF (12 mL) $\mathrm{nBuli}$ (1.10 equiv.) was added at $-78 \stackrel{\circ}{\circ} \mathrm{C}$ and the solution was stirred at the same temperature during 45 minutes. After this time $\mathrm{B}(\mathrm{OnBu})_{3}$ was added and the mixture was stirred at $-78^{\circ} \mathrm{C}$ during 1 hour, followed by 2 hours at room temperature. By the end of this time another solution was prepared by mixing bromo-2,3,3trimethylindolino[1,2-b]oxazoline (0.25 g, $0.89 \mathrm{mmol}, 1.0$ equiv.), $\mathrm{Pd}\left(\mathrm{PPh}_{3}\right)_{4}(0.10 \mathrm{~g}, 0.09 \mathrm{mmol}, 0.10 \mathrm{mmol})$, $2 \mathrm{M} \mathrm{Na}_{2} \mathrm{CO}_{3}(1.7 \mathrm{~mL})$ and 1 drop of ethylene glycol in $\operatorname{THF}(8.0 \mathrm{~mL})$. This solution was then added to the previously prepared borate and the reaction was refluxed overnight. The solvent was removed under reduced pressure and the crude material was taken up in DCM. This solution was washed with water and brine, dried $\left(\mathrm{MgSO}_{4}\right)$, concentrated under reduced pressure and purified by flash column chromatography (Petroleum ether/EtOAc, 9/1) to give the product (104 mg, 29\%) as a pink solid. m.p.: $156-157{ }^{\circ} \mathrm{C} ;{ }^{1} \mathrm{H} \mathrm{NMR}$ $(300 \mathrm{MHz}) \delta 1.22\left(6 \mathrm{H}, \mathrm{s}, \mathrm{CH}_{3}\right), 1.40\left(6 \mathrm{H}, \mathrm{s}, \mathrm{CH}_{3}\right), 1.47\left(6 \mathrm{H}, \mathrm{s}, \mathrm{CH}_{3}\right), 3.51-3.65\left(4 \mathrm{H}, \mathrm{m}, \mathrm{CH}_{2}\right), 3.68-3.91(4 \mathrm{H}$, $\left.\mathrm{m}, \mathrm{CH}_{2}\right), 6.78(2 \mathrm{H}, \mathrm{d}, J=8.1, \mathrm{CH}), 7.22(2 \mathrm{H}, \mathrm{t}, J=1.6, \mathrm{CH}), 7.31(2 \mathrm{H}, \mathrm{ddd} J=8.1,1.7,1.1, \mathrm{CH}) ;{ }^{13} \mathrm{C} \mathrm{NMR}$ $(75 \mathrm{MHz}) \delta 17.7\left(\mathrm{CH}_{3}\right), 21.0\left(\mathrm{CH}_{3}\right), 28.3\left(\mathrm{CH}_{3}\right), 47.2(\mathrm{C}), 50.3\left(\mathrm{CH}_{2}\right), 63.2\left(\mathrm{CH}_{2}\right), 109.4(\mathrm{C}), 112.2(\mathrm{CH})$, $121.2(\mathrm{CH}), 126.4(\mathrm{CH}), 135.9(\mathrm{C}), 140.6(\mathrm{C}), 149.6(\mathrm{C})$; IR $\overline{\mathrm{u}}=2961,2928,2881 \mathrm{~cm}^{-1}$; MS (ESI): $\mathrm{m} / z(\%)$ : $405(100)[\mathrm{M}+\mathrm{H}]^{+}$; HRMS (ESI): $\mathrm{m} / z$ calcd. for $\mathrm{C}_{26} \mathrm{H}_{33} \mathrm{~N}_{2} \mathrm{O}_{2}: 405.2537[\mathrm{M}+\mathrm{H}]^{+}$; found: 405.2539 .

\subsection{Instrumentation}

Electrochemical experiments were carried out with a Biologic SP-150 potentiostat driven by the EC-Lab software including ohmic drop compensation. Cyclic Voltammetry (CV) was performed in a three-electrode cell controlled at a temperature of $293 \mathrm{~K}$ in a glove box containing dry, oxygen-free ( $<1 \mathrm{ppm})$ argon. Working 
electrodes were glassy carbon planar disk electrodes $(\varnothing=3 \mathrm{~mm})$. Counter electrodes were platinum wires. Reference electrodes were $\mathrm{Ag} / \mathrm{AgNO}_{3}\left(0.01 \mathrm{M} \mathrm{CH} \mathrm{CH}_{3} \mathrm{CN}\right)$. Experiments were recorded in dry $\mathrm{HPLC}$-grade acetonitrile with tetrabutylammonium hexafluorophosphate $\left(\mathrm{Bu}_{4} \mathrm{NPF}_{6}\right.$, electrochemical grade, Fluka) as supporting electrolyte. All the potential reported were calibrated versus ferricinium/ferrocene couple $\left(\mathrm{Fc}^{+} / \mathrm{Fc}\right)$ (IUPAC Recommendation) [13]. Based on repetitive measurements, absolute errors on potentials were found to be around $+/-5 \mathrm{mV}$.

Time-resolved spectroelectrochemistry was performed using the already described home self-made cell [14-16]. The body of the cell and all the parts are made of Teflon in order to be compatible with a broad variety of solvents. Viton O-rings are used where needed in order to ensure gas-tightness. The working electrode is a $5 \mathrm{~mm}$ diameter disk of polished platinum inserted in a Teflon rod. It is mounted in the central well on a micrometer screw that permits fine adjustment of the distance between the electrode and the optical window, while maintaining the surface of the electrode parallel to the window. A distance of 25-200 $\mu \mathrm{m}$ between the surface of the electrode and the optical window was typically used in our experiments. Electrochemical measurements were carried out using a platinum wire counter electrode and a silver wire as a quasi-reference electrode with a Biologic SP-150 potentiostat driven by the EC-Lab software including ohmic drop compensation. Experiments were recorded in dry HPLC-grade acetonitrile with tetrabutylammonium hexafluorophosphate $\left(\mathrm{Bu}_{4} \mathrm{NPF}_{6}\right.$, electrochemical grade, Fluka) as supporting electrolyte. All solutions were prepared and transferred into the spectroelectrochemical cell in a glove box containing dry, oxygen-free (<1 ppm) argon, at room temperature. Spectrophotometric measurements were carried out with a homemade bench composed of different PRINCETON INSTRUMENTS modules (light sources, fibers, monochromators, spectroscopy camera and software). To start the two experiments at the same time, the two benches are synchronized with TTL signals.

Electrochemical simulations were performed by an electrochemical simulation program (DigiElch $7^{\mathrm{TM}}$ ), under the same conditions as experiments. Many electrochemical and chemical parameters can be optimized, and this makes the accuracy and the convergence of the simulation highly dependent on the number of parameters to be optimized.

\section{Results and discussion}

\subsection{Preliminary results}

All compounds were investigated by cyclic voltammetry under the same conditions $\left(0.1 \mathrm{M} \mathrm{TBAPF}_{6}\right.$ in $\mathrm{CH}_{3} \mathrm{CN}$, glassy carbon working electrode) and three distinct behaviours are clearly observed.

First, CVs of the BoX substituted with OMe exhibit a quasi-reversible one-electron process at $0.1 \mathrm{mV} . \mathrm{s}^{-1}$ (Figure 1a). Second, CVs of the BoX substituted with $\mathrm{Me}, \mathrm{F}, \mathrm{Cl}$ and $\mathrm{CHO}$ presents an irreversible oxidation wave at $0.1 \mathrm{mV} . \mathrm{s}^{-1}$ (Figure 1a). Third, CVs of the BoX substituted with $\mathrm{Br}$ or $\mathrm{H}$ show an irreversible oxidation peak followed, in the reverse scan at lower potentials, by the emergence of a unique quasi-reversible wave at $\sim 0.39 \mathrm{~V}$ (Figure $1 \mathrm{~b}$ ), ascribed to the reversible reduction of the product of the fast dimerization of radical cations [17]. 


\subsection{BoXs substituted with $\mathrm{OMe}, \mathrm{Me}, \mathrm{F}, \mathrm{Cl}$ and $\mathrm{CHO}$}

According to previous works [9], we can assume the ring opening of the BoX during oxidation, the kinetic rate of this opening being modulated by the substituents. The open BoX are stable in the range of potentials used and can be partially closed at a potential close to $-0.9 \mathrm{~V}$ vs $\mathrm{Fc}^{+} / \mathrm{Fc}$. The thermal ring-closure reaction kinetic of the BoX is frozen in our experimental conditions, leading a quasi-irreversible ring-opening reaction. The stepwise oxidation of each BoX can be described by an electrochemical mechanism with a first oneelectron process coupled to an irreversible chemical reaction ( $E C_{\text {irr }}$ process - Scheme 2 and Figure 2). To estimate the forward rate constant $\left(\mathrm{k}_{\mathrm{f}}\right)$ of the ring-opening reaction, a series of $\mathrm{CVs}$ was performed between $20 \mathrm{mV} \cdot \mathrm{s}^{-1}$ and $2000 \mathrm{mV} \cdot \mathrm{s}^{-1}$. An accurate estimate of $\mathrm{k}_{\mathrm{f}}$ is easy to make because the reversibility and irreversibility of CVs were observed at low and high scan rates, respectively (Figure 2). To determine thermodynamic $\left(E_{0}\right)$ and kinetic $\left(k_{f}\right)$ parameters of scheme 2 from our experimental data, a non-linear regression strategy applied to multiple data files simultaneously was carried out from the electrochemical simulation program DigiElch $7^{\mathrm{TM}}$ (Table 1). First at all, standard potentials $\left(\mathrm{E}^{0}\right)$ are substituent dependent to reach a range of $\sim 600 \mathrm{mV}$ between BoX-CHO and BoX-OMe. As expected [18-22], a linear dependence between the electrophilic substituent constants (Brown-Okamoto constant $\sigma_{p}{ }^{+}$for radical cations [23, 24]) and the redox potentials is observed (Figure 3), confirming the influence of the substituents on the electronic density of the electroactive center through the phenyl ring. Conversely, no clear trend of the forward rate constant $\left(\mathrm{k}_{\mathrm{f}}\right)$ of the ring-opening reaction vs. ${\sigma_{\mathrm{p}}}^{+}$was found, despite strong efforts.

To confirm the ring opening of the BoX during oxidation, time resolved spectroelectrochemical experiments (CVs and chronoamperometry experiments) were performed on all BoX derivatives (Figure 4). The oxidation of BoX-R leads to the formation of (BoX-R) $)^{+}$, characterized by an absorption band between 450-480 nm depending of the substituent. This absorption band disappears with time (exponential decrease - Figure 4B and $4 \mathrm{C}$ ) in order to produce an open BoX (i.e. no absorption band is observed between $350 \mathrm{~nm}$ and $900 \mathrm{~nm}$ as described by Raymo and al. [25]). The good agreement between the simulated concentration-time profiles and experimental data in thin layer conditions (Figure 4D) allows the assignment of the absorption band at $450 \mathrm{~nm}$ (Figure 4C) to the $\left(\right.$ BoX-R) ${ }^{+}$.

\subsection{BoXs substituted with $\mathrm{H}$ and $\mathrm{Br}$}

To support the assignment of the reversible wave observed in reverse scan at $0.39 \mathrm{~V}$ to the reduction of the dimer of radical cations, the BoX dimer (i.e. BoX-BoX) was synthetized (Scheme 1). As expected, CVs of BoX-BoX exhibit a unique oxidation wave characterized by two very closed one-electron processes, at the same potential as those observed with the BoX-H and BoX-Br (Figure 1). As previously mentioned with similar systems [22], these two systems can be simplified to a two-electrons process, allowing to estimate the redox potential of BoX-BoX to 0,39 V by fitting modelled CVs with experimental CVs.

In addition, time resolved spectroelectrochemical experiments, carried out on $\mathbf{B o X}-\mathbf{B r}, \mathbf{B o X}-\mathbf{H}$ and $\mathbf{B o X}-\mathbf{B o X}$, show that the oxidations of the BoX-H, BoX-Br and BoX-BoX generate a large absorption band close to 500 $\mathrm{nm}$, assigned to the oxidized dimer BoX-BoX ${ }^{2+}$ (Figure 5). Note that the absorption band of radical cation of the BoX-BoX can be also observed at $750 \mathrm{~nm}$ during the reversible oxidation of the BoX-BoX (Figure 5), confirming that the oxidation of the BoX-BoX is not a pure two-electron process but composed of two successive and very close one-electron steps. 
Contrary to the previous works of Feringa et al. [8] on spiropyran derivatives, the kinetic of the dimerization of the radical cation is competing with the one of the ring-opening reaction of the boxes (Scheme 2). Moreover, differences can be also explained by the fact that both BoX derivatives do not follow the same reaction pathway to yield dimer. Indeed, in the case of the $\mathbf{B o X}-\mathbf{B r}$, we can assume that just after the formation of the dimer (BoX-Br $)_{2}{ }^{2+}$, there is release of $\mathrm{Br}_{2}$ and formation of the oxidized dimer $\mathbf{B o X - B o X}{ }^{2+}$. In the case of BoX-H, and as the Feringa's model proposes, we can assume that the formation of the dimer $(\mathrm{BoX}-\mathrm{H})_{2}{ }^{2+}$ leads to release $2 \mathrm{H}^{+}$and generates the neutral dimer BoX-BoX, which can oxidize immediately to (BoX$\mathrm{H}_{2}{ }_{2}^{2+}$ at this high potential. Finally the release of $\mathrm{H}^{+}$could promote, in the vicinity of the electrode, a spontaneous opening of the BoX-H as shown in many studies [26-28].

According to these first results, the stepwise oxidation could be proposed in agreement with three oneelectron processes and two or three charge-coupled chemical reactions (i.e. dimerization and ring-opening reactions) (Scheme 3). To validate this model, we performed a set of voltammograms by varying the scan rate (from $20 \mathrm{mV} . \mathrm{s}^{-1}$ to $\left.2000 \mathrm{mV} . \mathrm{s}^{-1}\right)$ and the concentration of the initial BoX derivatives $\left(310^{-3} \mathrm{M}, 310^{-4} \mathrm{M}, 3\right.$ $10^{-5} \mathrm{M}$ ), the dimerization efficiency being highly dependent on the latter parameter. The good agreement between experimental data and modelized $\mathrm{CVs}$ in a whole range of concentration and scan rate supports the model of the stepwise oxidation of BoX-Br and BoX-H (Figures 6 and 7 and Table 2). Concerning the BoX$\mathrm{Br}$ derivative (Figure 6), an increase in the scan rate or a decrease in the concentration induces a slight return of the reversibility of the electrochemical system $\mathbf{B o x}-\mathbf{B r}^{+} / \mathbf{B o X}-\mathbf{B r}$. We also observe that the dimerization reaction is more efficient than the ring-opening reaction. Concerning the BoX-H derivative (Figure 7), the trend is respected despite greater difficulty to adjust experimental CVs to the proposed model (many reactions and problems of stoichiometry). Nevertheless, the dimer formation is favoured and $\mathrm{H}^{+}$ formation during the dimerization induces, in the vicinity of the electrode, a local acidity change that reduces the concentration of BoX-H by rapid spontaneous opening.

Electrochemical simulations and multi-data fittings confirm that the fitted redox potentials (Table 2) of the Box-Br ${ }^{+} / \mathbf{B o X}-\mathbf{B r}$ and $\mathbf{B o x}-\mathrm{H}^{+} / \mathbf{B o X}-\mathbf{H}$ vs. Brown-Okamoto constant agree with the same trend of the other BoX derivatives (Figure 3). The global dimerization constant $\left(\mathrm{kf}_{2}\right)$ for BoX-H is greater than the one of BoX-Br, and is in the same order of magnitude $\left(\mathrm{kf}>10^{6}\right)$ as that observed for different systems, such as dimerization of $\alpha$-thiophenes [29,30] or dithiafulvenes [22] and polymerizations of aniline [31], thiophenes $[32,33]$ or pyrroles $[32,34]$ derivatives. The simulated concentration-time profiles in thin layer conditions (Figure 5D) combined to the spectroelectrochemistry measurements show that the absorption bands at $\sim 500$ $\mathrm{nm}$ and above $750 \mathrm{~nm}$ are clearly assigned to the $\mathbf{B o X}-\mathbf{B o X}^{2+}$, and the oxidized BoX-BoX ${ }^{+}$, respectively.

\section{Conclusions}

This work presents original strategy to modulate the properties of the indolino[2,1-b]oxazolidine core appropriately substituted in position 5 (para-substitution of the phenyl ring) by acceptor or donor groups $(\mathrm{CHO}, \mathrm{OMe}, \mathrm{Me}, \mathrm{F}, \mathrm{H}, \mathrm{Cl}, \mathrm{Br}$ ). These $\mathrm{BoX}$ derivatives were investigated with electrochemical and spectroelectrochemical characterisations. They show different behaviours upon oxidation and demonstrate the dependence of the nature of these groups on the BoX derivatives upon oxidation.

The redox potentials of BoX derivatives correlate with the Brown-Okamoto constants $\sigma_{p}{ }^{+}$confirming the influence of the substituents on electronic density of the electroactive center through the phenyl ring. 
The stepwise oxidation of BoX derivatives depends on the para-substitution of the phenyl ring. Indeed, BoX substituted with OMe exhibits a quasi-reversible one-electron process, BoX substituted with $\mathrm{Me}, \mathrm{F}, \mathrm{Cl}$ and $\mathrm{CHO}$ present an irreversible oxidation wave leading to the open form of the BoX core, and BoX substituted with $\mathrm{Br}$ or $\mathrm{H}$ show an irreversible oxidation peak followed, in the reverse scan at lower potentials, by the emergence of a unique reversible wave characteristic of the dimer BoX-BoX.

The results demonstrate the potential of the indolino[2,1-b]oxazolidine core in view of its integration into multi-responsive systems, the para substitution of the phenyl ring being an additional asset for the creation of new types of molecular switch.

\section{Acknowledgments}

This work was funded by the PHOEBUS project which is supported by the "Agence Nationale de la Recherche" (ANR-France). The authors thank Flavy Alévêque for her critical reading of the manuscript, and, Philippe Blanchard and Piétrick Hudhomme for scientific discussions. 


\section{References}

[1] J. Andreasson, U. Pischel, Smart molecules at work-mimicking advanced logic operations, Chemical Society Reviews, 39 (2010) 174-188.

[2] B.L. Feringa, W.R. Browne, Molecular Switches, Wiley, 2011.

[3] D. Gust, J. Andreasson, U. Pischel, T.A. Moore, A.L. Moore, Data and signal processing using photochromic molecules, Chemical Communications, 48 (2012) 1947-1957.

[4] R. Bartnik, S. Lesniak, G. Mloston, T. Zielinski, K. Gebicki, Cationic Dye Derivatives of 1-(2-hydroxyethyl)2-styryl-3,3-dimethyl-3H-indole, Chem. Stosow., 34 (1990) 325.

[5] R. Bartnik, G. Mloston, Z. Cebulska, Synthesis and Chain-ring Tautomerism of 1-(2-hydroxyethyl)-3,3dimethyl-3H-indole Derivative Cyanine dyes, Chem. Stosow., 34 (1990) 343.

[6] L. Sanguinet, J.-L. Pozzo, V. Rodriguez, F. Adamietz, F. Castet, L. Ducasse, B. Champagne, Acido- and Phototriggered NLO Properties Enhancement, The Journal of Physical Chemistry B, 109 (2005) 1113911150.

[7] G. Sevez, J. Gan, S. Delbaere, G. Vermeersch, L. Sanguinet, E. Levillain, J.-L. Pozzo, Photochromic performance of a dithienylethene-indolinooxazolidine hybrid, Photochemical \& Photobiological Sciences, 9 (2010) 131-135.

[8] O. Ivashenko, J.T. van Herpt, P. Rudolf, B.L. Feringa, W.R. Browne, Oxidative electrochemical aryl C-C coupling of spiropyrans, Chemical Communications, 49 (2013) 6737-6739.

[9] G. Szalóki, O. Alévêque, J.-L. Pozzo, R. Hadji, E. Levillain, L. Sanguinet, Indolinooxazolidine: A Versatile Switchable Unit, The Journal of Physical Chemistry B, 119 (2015) 307-315.

[10] G. Szalóki, L. Sanguinet, J. Org. Chem. , DOI: 10.1021/acs.joc.5b00282 (2015).

[11] C. Niu, Y. Song, L. Yang, Synthesis of 5'-Functionalized Indolinospiropyrans with Vinylene Unit as Linker, Chinese Journal of Chemistry, 27 (2009) 2001-2006.

[12] L. Sheng, M. Li, S. Zhu, H. Li, G. Xi, Y.-G. Li, Y. Wang, Q. Li, S. Liang, K. Zhong, S.X.-A. Zhang, Hydrochromic molecular switches for water-jet rewritable paper, Nat Commun, 5 (2014).

[13] G. Gritzner, J. Kuta, Recommendations on reporting electrode potentials in nonaqueous solvents (Recommendations 1983), in: Pure and Applied Chemistry, vol. 56, 1984, pp. 461.

[14] O. Alévêque, E. Levillain, L. Sanguinet, Spectroelectrochemistry on electroactive self-assembled monolayers: Cyclic voltammetry coupled to spectrophotometry, Electrochem Commun, 51 (2015) 108-112.

[15] F. Gaillard, E. Levillain, Visible Time-Resolved Spectroelectrochemistry - Application to Study of the Reduction of Sulfur (S-8) in Dimethylformamide, J Electroanal Chem, 398 (1995) 77-87.

[16] M. Dias, P. Hudhomme, E. Levillain, L. Perrin, Y. Sahin, F.X. Sauvage, C. Wartelle, Electrochemistry coupled to fluorescence spectroscopy: a new versatile approach, Electrochem Commun, 6 (2004) 325-330.

[17] A.J. Bard, L.R. Faulkner, Electrochemical methods: fundamentals and applications, Wiley India Pvt. Ltd., 2006.

[18] D.S. Bhuvaneshwari, K.P. Elango, Substituent and Solvent Effects on the Electro-chemical Oxidation of para-and meta-Substituted Anilines, Zeitschrift fur Naturforschung B-Journal of Chemical Sciences, 61 (2006) 1254-1260.

[19] D.T. Glatzhofer, M.C. Morvant, Substituent effects on the electrochemical oxidation of N,N',N"-triphenyl1,3,5-triaminobenzenes, Journal of Physical Organic Chemistry, 11 (1998) 731-736.

[20] C.P. Andrieux, P. Hapiot, J. Pinson, J.M. Saveant, Determination of formal potentials of chemically unstable redox couples by second-harmonic alternating current voltammetry and cyclic voltammetry. Application to the oxidation of thiophenoxide ions, Journal of the American Chemical Society, 115 (1993) 7783-7788.

[21] P. Hapiot, J. Pinson, N. Yousfi, Substitutent effects on the redox properties of phenolates in acetonitrile. One-electron redox potentials, New journal of chemistry, 16 (1992) 877-881.

[22] P. Hapiot, D. Lorcy, A. Tallec, R. Carlier, A. Robert, Mechanism of Dimerization of 1,4-Dithiafulvenes into TTF Vinylogues, The Journal of Physical Chemistry, 100 (1996) 14823-14827.

[23] H.C. Brown, Y. Okamoto, Electrophilic substituent constants, Journal of the American Chemical Society, 80 (1958) 4979-4987.

[24] C. Hansch, A. Leo, R. Taft, A survey of Hammett substituent constants and resonance and field parameters, Chemical Reviews, 91 (1991) 165-195.

[25] M. Tomasulo, S. Sortino, A.J.P. White, F.M. Raymo, Fast and stable photochromic oxazines, J Org Chem, 70 (2005) 8180-8189.

[26] G. Szalóki, G. Sevez, J. Berthet, J.-L. Pozzo, S. Delbaere, A Simple Molecule-Based Octastate Switch, Journal of the American Chemical Society, 136 (2014) 13510-13513.

[27] F. Mançois, J.-L. Pozzo, J. Pan, F. Adamietz, V. Rodriguez, L. Ducasse, F. Castet, A. Plaquet, B. Champagne, Two-Way Molecular Switches with Large Nonlinear Optical Contrast, Chemistry - A European Journal, 15 (2009) 2560-2571. 
[28] F. Mançois, L. Sanguinet, J.-L. Pozzo, M. Guillaume, B. Champagne, V. Rodriguez, F. Adamietz, L. Ducasse, F. Castet, Acido-Triggered Nonlinear Optical Switches: Benzazolo-oxazolidines, The Journal of Physical Chemistry B, 111 (2007) 9795-9802.

[29] M. Barth, S. Guilerez, G. Bidan, G. Bras, M. Lapkowski, Electrochemical investigation of regioregular alkyl substituted oligothiophenes, Electrochim Acta, 45 (2000) 4409-4417.

[30] Z. Xu, D. Fichou, G. Horowitz, F. Garnier, Electrochemical synthesis of alpha-conjugated octi- and decithienyl oligomers, Journal of Electroanalytical Chemistry and Interfacial Electrochemistry, 267 (1989) 339-342.

[31] C.P. Andrieux, P. Audebert, P. Hapiot, M. Nechtschein, C. Odin, Fast Scan Rate Cyclic Voltammetry for Conducting Polymers Electropolymerized on Ultramicroelectrodes, J Electroanal Chem, 305 (1991) $153-162$. [32] P. Audebert, P. Hapiot, Fast electrochemical studies of the polymerization mechanisms of pyrroles and thiophenes. Identification of the first steps. Existence of m-dimers in solution, Synthetic Metals, 75 (1995) 95102.

[33] I.F. Perepichka, D.F. Perepichka, Handbook of Thiophene-Based Materials: Applications in Organic Electronics and Photonics, 2 Volume Set, Wiley, 2009.

[34] C.P. Andrieux, P. Audebert, P. Hapiot, J.M. Saveant, Identification of the 1st Steps of the Electrochemical Polymerization of Pyrroles by Means of Fast Potential Step Techniques, J Phys Chem-Us, 95 (1991) 10158-10164. 


\section{Tables}

Table 1. Electrochemical parameters of BoX-R extracted ${ }^{*}$ from a set of CVs with DigiElch $7^{\mathrm{TM}}$.

\begin{tabular}{|c|c|c|c|c|c|c|c|}
\hline & BoX-MeO & BoX-Me & BoX-F & BoX-H & BoX-Cl & BoX-Br & BoX-CHO \\
\hline $\mathrm{E}^{0}(\mathrm{~V}$ vs Fc $/ \mathrm{Fc})$ & $0.42_{ \pm 0.02}$ & $0.57_{ \pm 0.02}$ & $0.70 \pm 0.02$ & $0.64_{ \pm 0.04}$ & $0.74_{ \pm 0.02}$ & $0.75_{ \pm 0.03}$ & $0.97 \pm 0.02$ \\
\hline $\mathrm{k}_{\mathrm{f} 1}\left(\mathrm{~s}^{-1}\right)$ & $0.005_{ \pm 10 \%}$ & $0.440_{ \pm 10}$ & $0.058_{ \pm 10 \%}$ & $0.700_{330}$ & $0.027_{ \pm 10}$ & $0.090 \pm 20 \%$ & $0.630_{ \pm 10 \%}$ \\
\hline$\sigma_{\mathrm{p}}+$ & -0.78 & -0.31 & -0.07 & 0.00 & 0.11 & 0.15 & 0.73 \\
\hline
\end{tabular}

* Diffusion constants (D) of species between $110^{-5} \mathrm{~cm}^{2} / \mathrm{s}^{-1}$ and $510^{-5} \mathrm{~cm}^{2} / \mathrm{s}^{-1}$ and standard heterogeneous rate constants $\left(\mathrm{k}_{\mathrm{s}}\right)$ between $210^{-2} \mathrm{~cm} \cdot \mathrm{s}^{-1}$ and $1010^{-2} \mathrm{~cm} \cdot \mathrm{s}^{-1}$, were used to test the accuracy and convergence of these two parameters. Errors are estimated based on the spread of all experimental errors and errors of the fit. Parameters were extracted from simulations based on schemes 2 and 3.

Table 2. Electrochemical parameters of BoX-H and BoX-Br extracted ${ }^{*}$ from a set of CVs with DigiElch $7^{\mathrm{TM}}$.

\begin{tabular}{|c|c|c|c|c|c|}
\hline & $\begin{array}{c}\mathrm{E}^{0}{ }_{1}(\mathrm{Vvs} \\
\left.\mathrm{Fc}^{+} / \mathrm{Fc}\right)\end{array}$ & $\begin{array}{c}\mathrm{E}^{0}{ }_{2}(\mathrm{Vvs} \\
\left.\mathrm{Fc}^{+} / \mathrm{Fc}\right)\end{array}$ & $\mathrm{K}_{\mathrm{f} 1}\left(\mathrm{~s}^{-1}\right)$ & $\mathrm{k}_{\mathrm{f} 2}\left(\mathrm{M}^{-1} \mathrm{~s}^{-1}\right)$ & $\mathrm{k}_{\mathrm{f} 3}\left(\mathrm{~s}^{-1}\right)$ \\
\hline BoX-Br & $0.75_{ \pm 0.03}$ & $0.39_{ \pm 0.02}$ & $0.09_{ \pm 20 \%}$ & $1900_{ \pm 20 \%}$ & \\
\hline BoX-H & $0.64_{ \pm 0.04}$ & $0.39_{ \pm 0.02}$ & $0.70 \pm 30 \%$ & $410^{5} \pm 30 \%$ & $110^{4} \pm 30 \%$ \\
\hline
\end{tabular}

* Diffusion constants (D) of species between $110^{-5} \mathrm{~cm}^{2} / \mathrm{s}^{-1}$ and $510^{-5} \mathrm{~cm}^{2} / \mathrm{s}^{-1}$ and standard heterogeneous rate constants $\left(k_{\mathrm{s}}\right)$ between $210^{-2} \mathrm{~cm} \cdot \mathrm{s}^{-1}$ and $1010^{-2} \mathrm{~cm} \cdot \mathrm{s}^{-1}$, were used to test the accuracy and convergence of these two parameters. Errors are estimated based on the spread of all experimental errors and errors of the fit. Parameters were extracted from approximate simulations based on schemes 3. 


\section{Schemes}
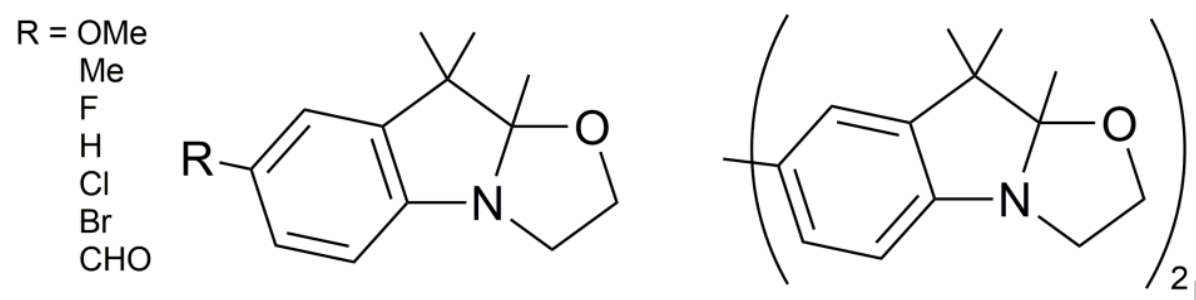

Scheme 1. BoX-R derivatives and BoX-BoX.

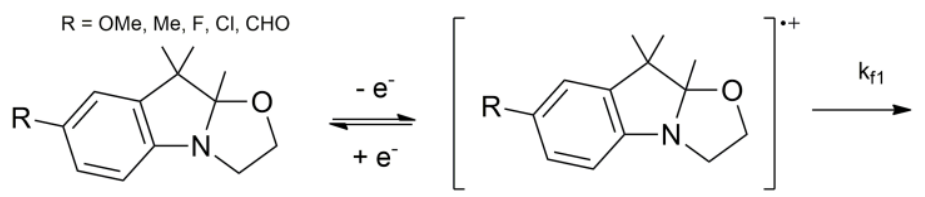<smiles>[R]c1ccc2c(c1)C(C)(C)C(C)=[N+]2CCO</smiles>

$$
\begin{aligned}
& \mathrm{B} \stackrel{\mathrm{E}^{0}}{\rightleftharpoons} \mathrm{B}^{+}+\mathrm{e}^{-} \\
& \mathrm{B}^{+} \stackrel{\mathrm{k}_{\mathrm{f} 1}}{\longrightarrow} \mathrm{Bo}^{\longrightarrow}
\end{aligned}
$$

Scheme 2. $\mathrm{EC}_{\text {irr }}$ mechanism involved for BoX substituted with $\mathrm{OMe}, \mathrm{Me}, \mathrm{F}, \mathrm{Cl}$ and $\mathrm{CHO}$. Inset, the mechanism used for numerical simulations. B refers to the BoX-R and Bo to the open BoX-R. 

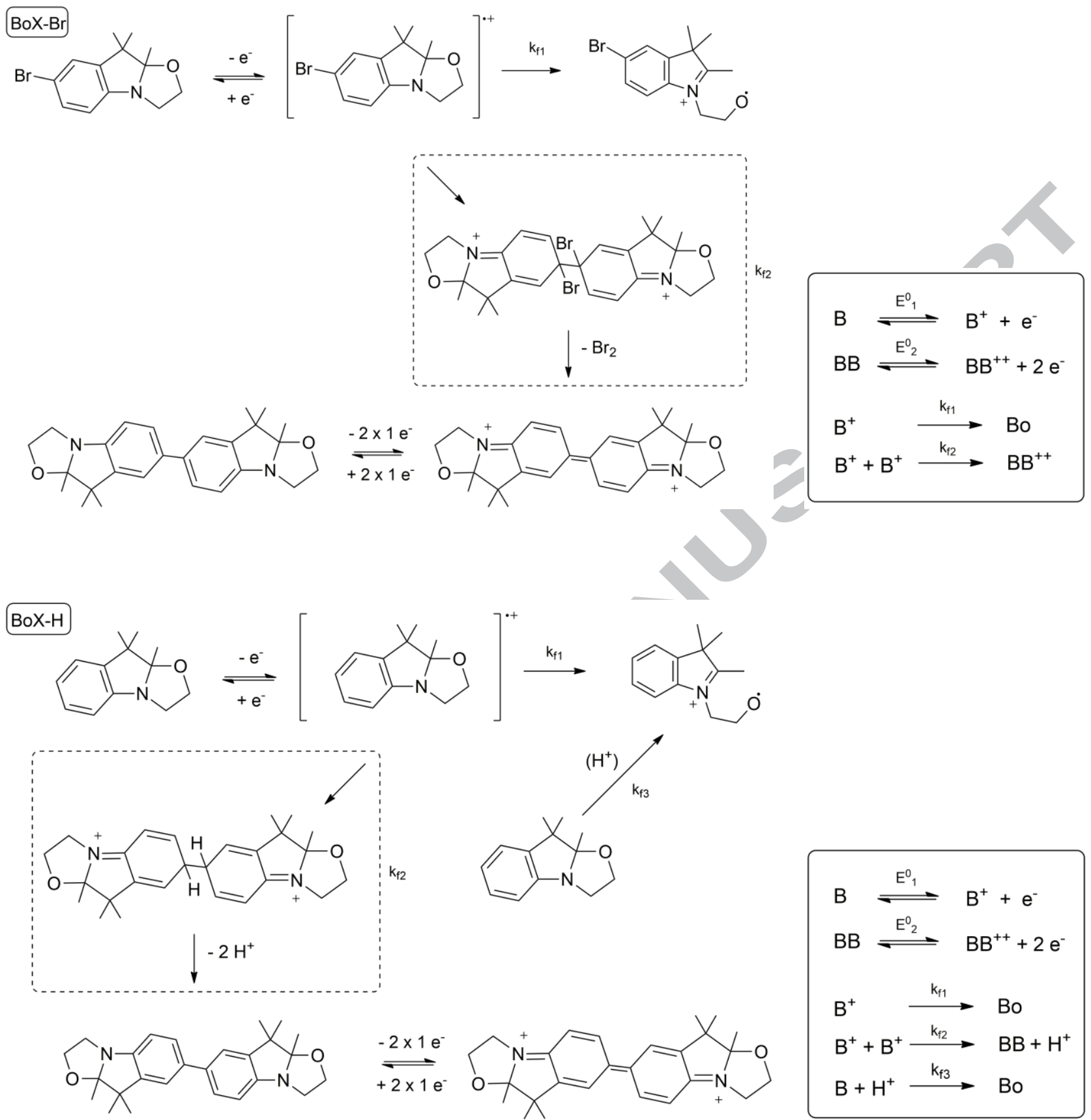

Scheme 3. Electrochemical mechanisms proposed for BoX-Br (top) and BoX-H (bottom). Insets, the mechanisms used for numerical simulations (stœchiometry is not perfectly equilibrated because DigiElch $7^{\mathrm{TM}}$ software does not manage stoichiometric coefficients different from unity). B refers to the BoX-R, Bo to the open BoX-R and BB to the BoX-BoX. 
Figures
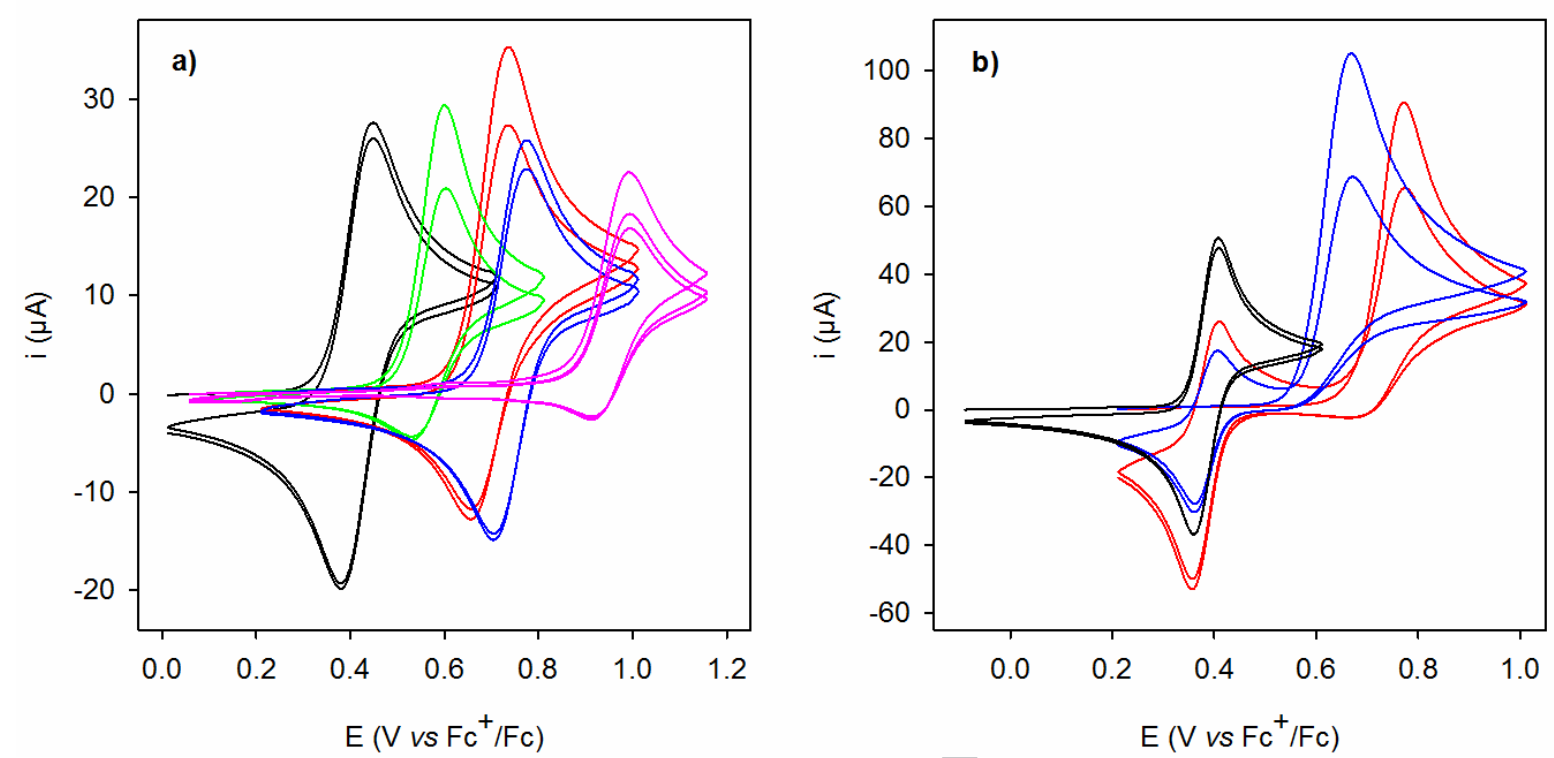

Figure 1. Cyclic voltammograms of the different BoX-R derivatives $\left(10^{-3} \mathrm{M}\right)$ in $0.1 \mathrm{M} \mathrm{TBAPF} / \mathrm{CH}_{3} \mathrm{CN}$ on glassy carbon $\left(A=0.07 \mathrm{~cm}^{2}\right)$ at $100 \mathrm{mV}^{-s^{-1}}$. a) BoX-OMe (dark), BoX-Me (green), BoX-F (red), BoX-Cl (blue), BoX-CHO (pink), b) BoX-BoX (dark), BoX-H (blue), BoX-Br (red). 

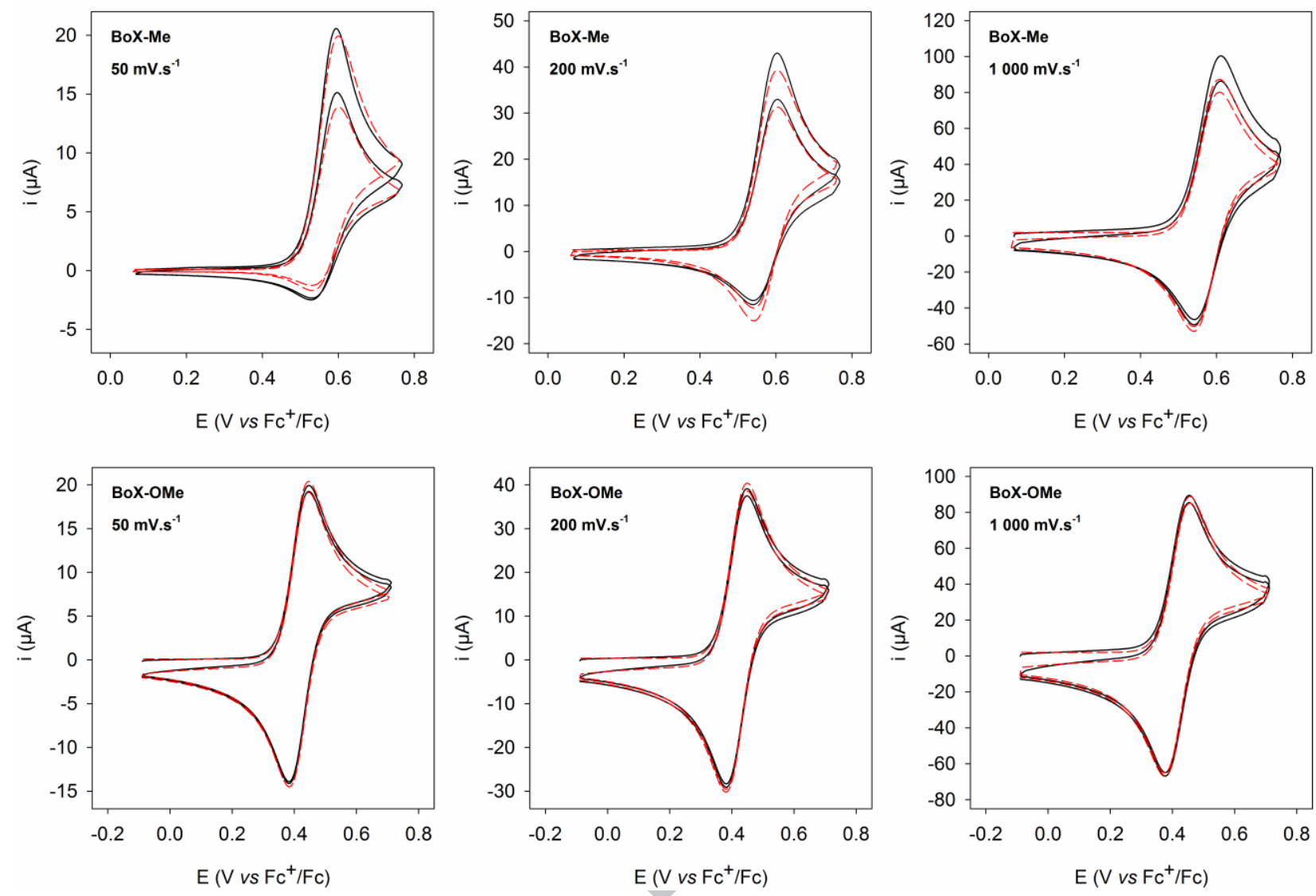

Figure 2. Black lines: Cyclic voltammograms of BoX-Me (top) and BoX-OMe (bottom) at different scan rates (left : $50 \mathrm{mV} . \mathrm{s}^{-1}$; middle: $200 \mathrm{mV} . \mathrm{s}^{-1}$; right: $1000 \mathrm{mV} . \mathrm{s}^{-1}$ ) in $0.1 \mathrm{M} \mathrm{TBAPF} / \mathrm{CH}_{3} \mathrm{CN}$ on glassy carbon electrode at $10^{-3} \mathrm{M}$. Note that the baselines were subtracted on CVs. Red short-short line: electrochemical simulations performed from experiments (BoX-Me: $E^{0}{ }_{1}=0.57 \mathrm{~V}, \mathrm{k}_{\mathrm{f} 1}=0.44 \mathrm{~s}^{-1}$. BoX-MeO: $\mathrm{E}^{0}{ }_{1}=0.42 \mathrm{~V}, \mathrm{k}_{\mathrm{f} 1}=$ $0.005 \mathrm{~s}^{-1}, \alpha=0.5, \mathrm{D}=10^{-5} \mathrm{~cm}^{2} . \mathrm{s}^{-1}$ and $\mathrm{k}_{\mathrm{s}}=0.01 \mathrm{~cm} \cdot \mathrm{s}^{-1}$ for all BoX-R). 


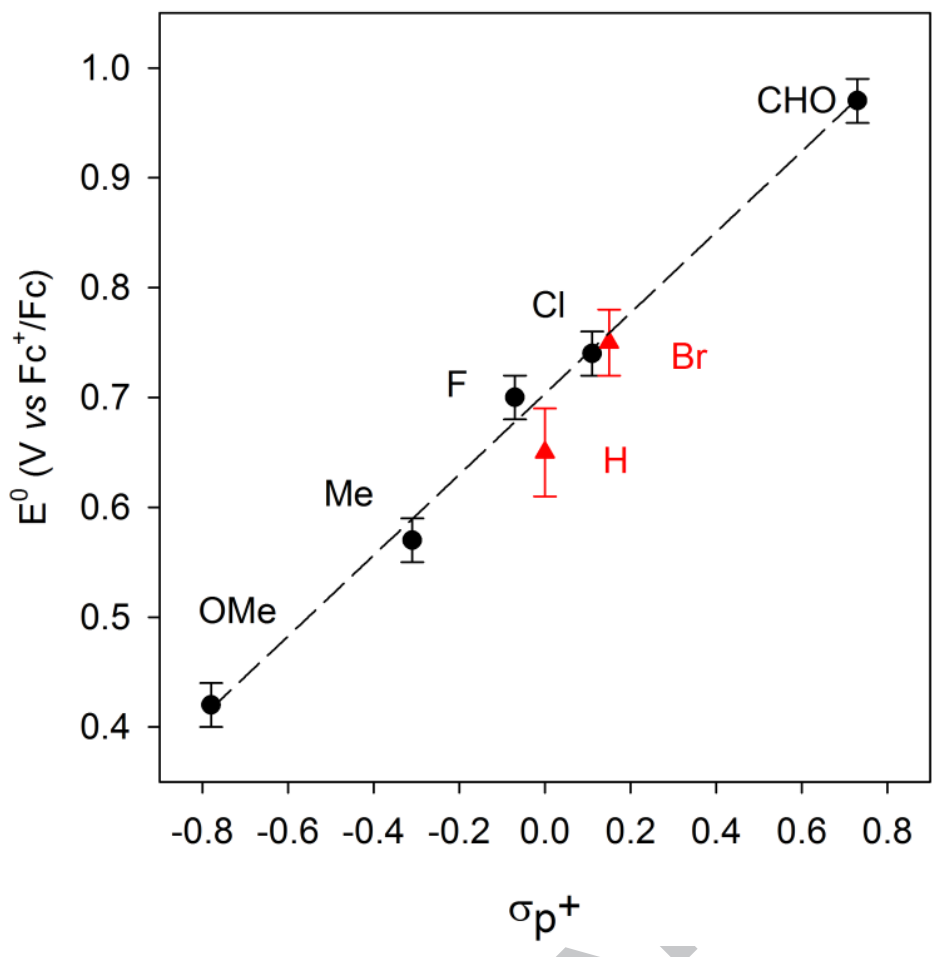

Figure 3. Linear correlation of the redox potential $E^{0}(V)$ with the Brown-Okamoto constant $\sigma^{+}$for various substituents. Black circles: BoX-R derivatives leading to an open form. Red triangle: BoX-R derivatives leading to an open form and to a dimer. Errors are estimated based on the spread of all experimental errors and errors of the fit. 


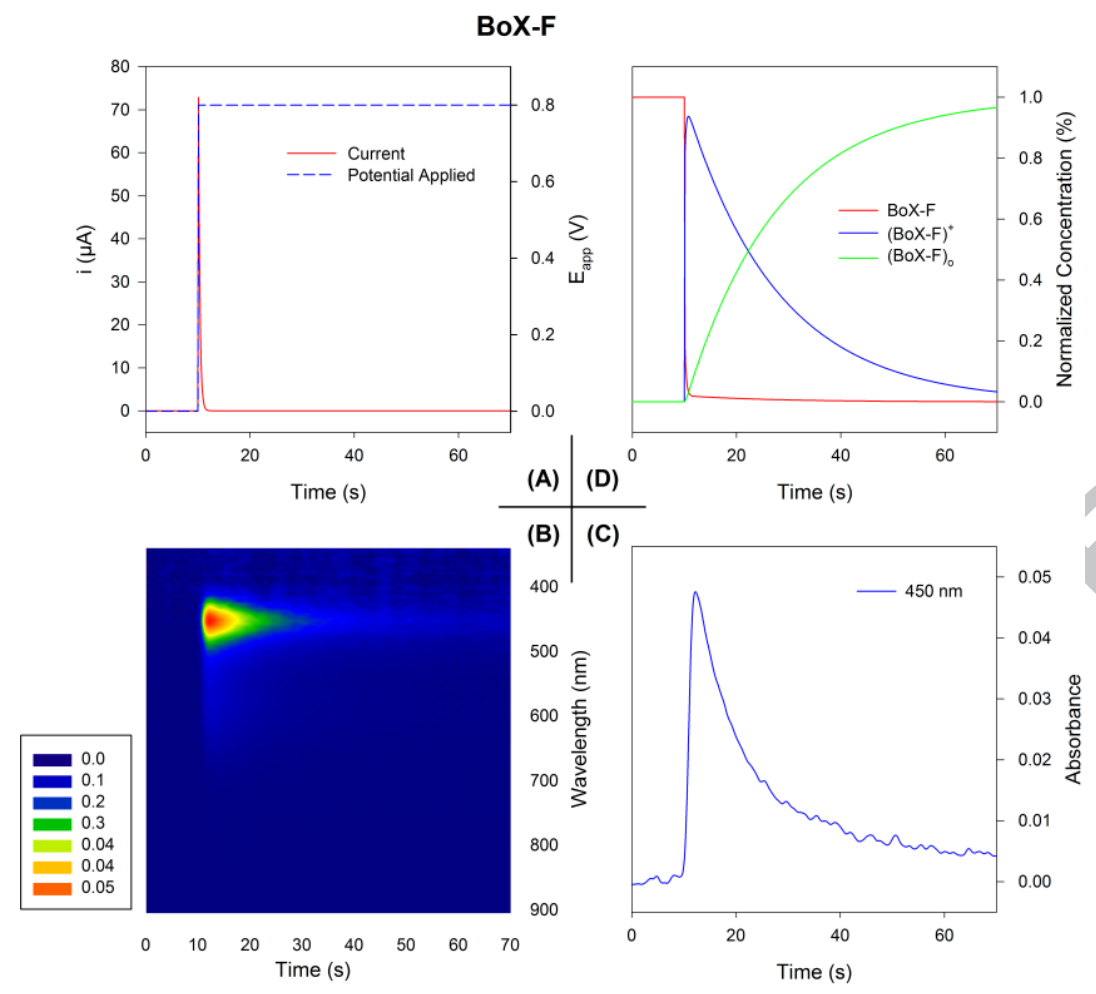

Figure 4. Spectroelectrochemistry experiments of $\mathbf{B o X}-\mathbf{F}$ in $0.1 \mathrm{M} T \mathrm{TBAPF}_{6} / \mathrm{CH}_{3} \mathrm{CN}$ on glassy carbon electrode in thin layer conditions (close to $50 \mu \mathrm{m}$ ) at $0.8 \mathrm{~V}$ and $293 \mathrm{~K}$. (A) Potential applied and current $v s$ time representation. (B) 3D representation (wavelength, time) vs (absorbance). (C) Absorbance representation vs time at $450 \mathrm{~nm}$ (D) Concentration-time profiles of each simulated species in the thin layer $(50 \mu \mathrm{m})$ calculated from electrochemical simulations. 

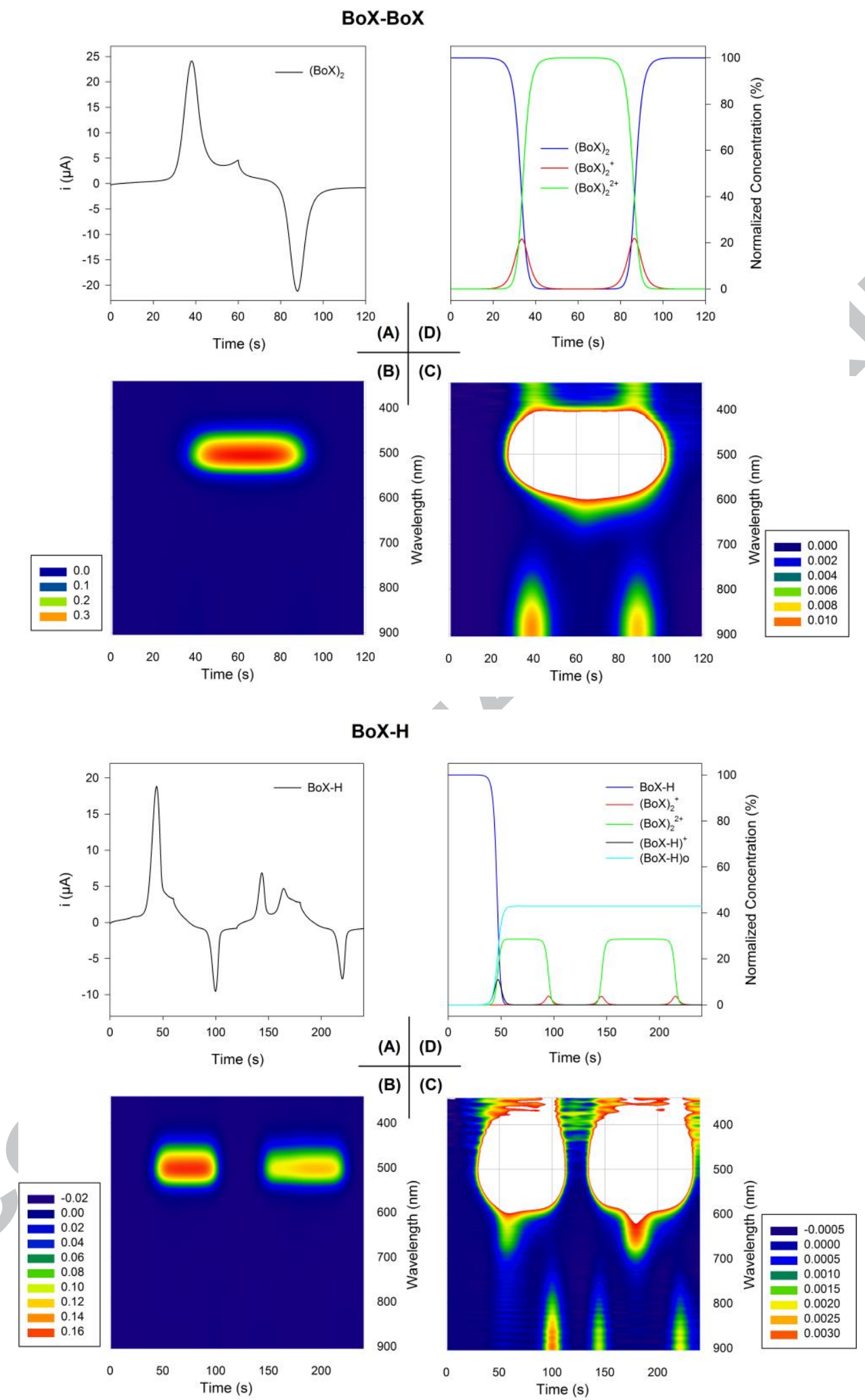

Figure 5. Spectroelectrochemistry experiments of BoX-BoX (top) and BoX-H (bottom) in $0.1 \mathrm{M}$ TBAPF $_{6} / \mathrm{CH}_{3} \mathrm{CN}$ on glassy carbon electrode in thin layer conditions (close to $50 \mu \mathrm{m}$ ) at $10 \mathrm{mV} \cdot \mathrm{s}^{-1}$ and $293 \mathrm{~K}$. (A) CV in current vs time representation. (B) 3D representation (wavelength, time) vs (absorbance). (C) Absorbance zoom of the $3 \mathrm{D}$ representation (D) concentration-time profiles of each simulated species in the thin layer $(50 \mu \mathrm{m})$ calculated from electrochemical simulations of Figure 5 and 6. 

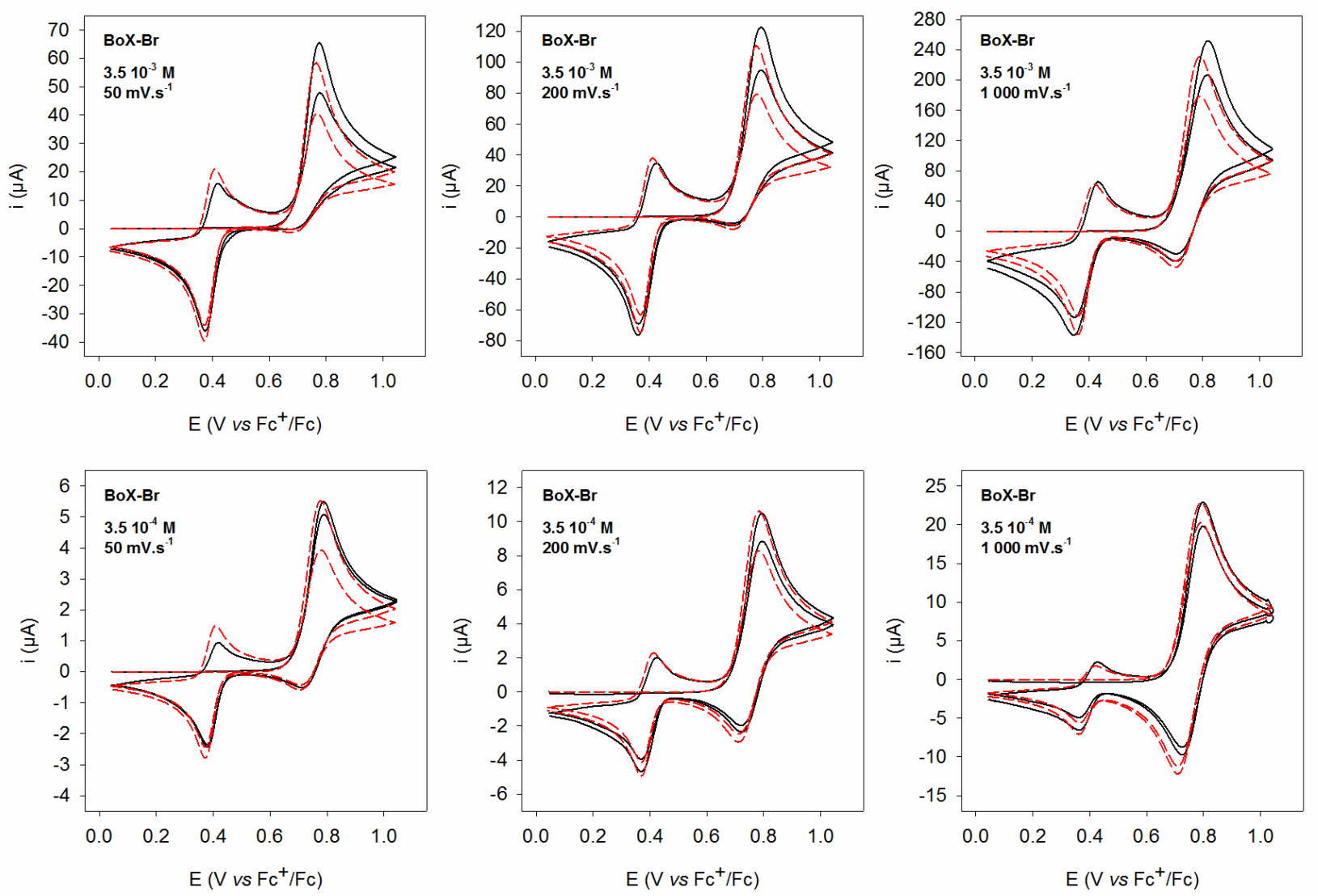

Figure 6. Black lines: Cyclic voltammograms of $\mathrm{BoX}-\mathrm{Br}$ at different concentrations (top : $3.510^{-3} \mathrm{M}$; bottom : $3.510^{-4} \mathrm{M}$ ) and at different scan rates (left : $50 \mathrm{mV} . \mathrm{s}^{-1}$; middle : $200 \mathrm{mV} . \mathrm{s}^{-1}$; right : $1000 \mathrm{mV} . \mathrm{s}^{-1}$ ) in $0.1 \mathrm{M}$ $\mathrm{TBAPF}_{6} / \mathrm{CH}_{3} \mathrm{CN}$ on glassy carbon electrode. Note that the baselines were subtracted on CVs. Red shortshort line: electrochemical simulations performed from experiments: $\mathrm{E}_{1}^{0}=0.75 \mathrm{~V}, \mathrm{E}^{0}{ }_{2}=0.39 \mathrm{~V}, \mathrm{k}_{\mathrm{f} 1}=0.09 \mathrm{~s}^{-1}$, $\mathrm{k}_{\mathrm{f} 2}=1900 \mathrm{M}^{-1} \mathrm{~s}^{-1}, \alpha=0.5, \mathrm{D}=10^{-5} \mathrm{~cm}^{2} \cdot \mathrm{s}^{-1}$ and $\mathrm{k}_{\mathrm{s}}=0.01 \mathrm{~cm} \cdot \mathrm{s}^{-1}$. 

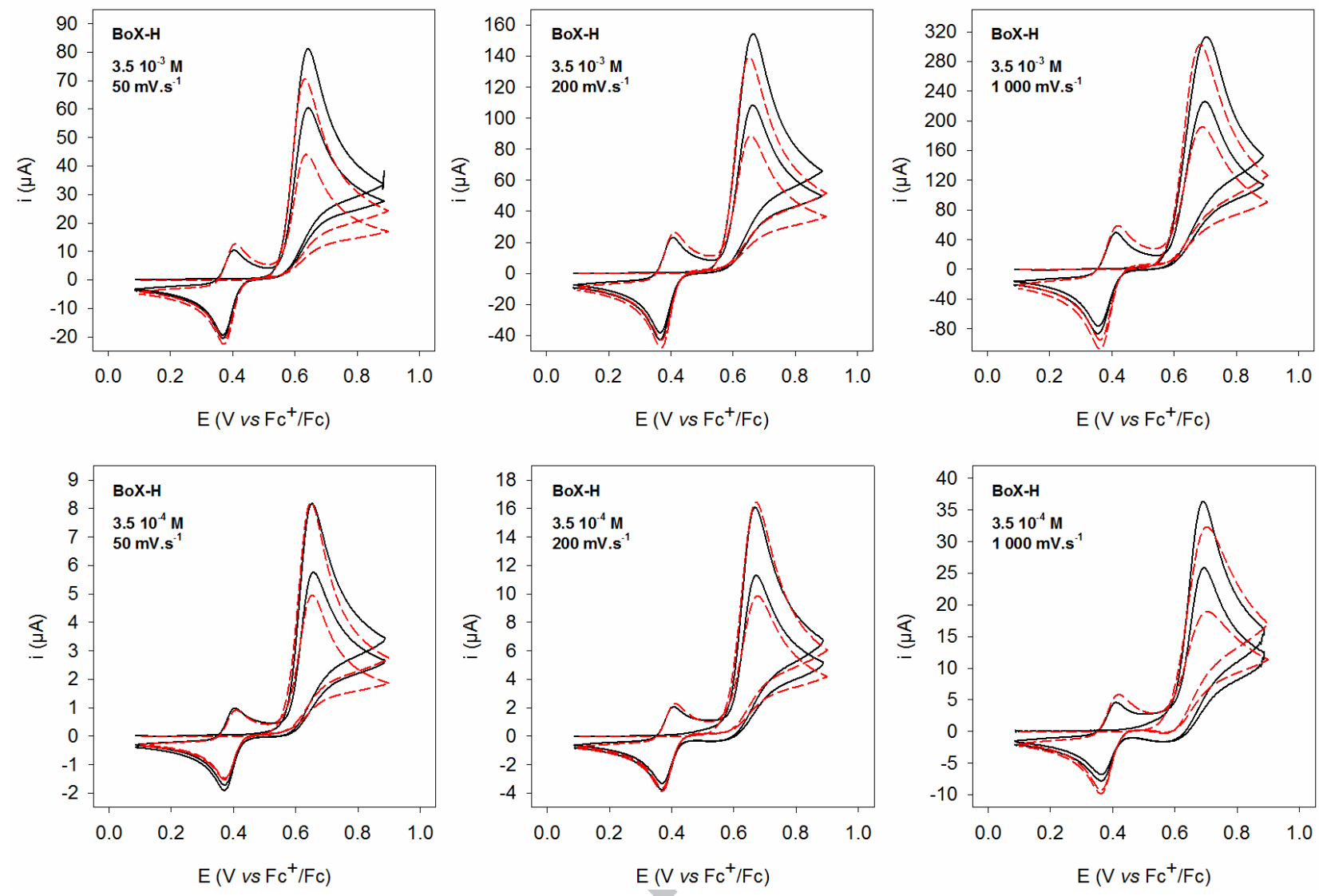

Figure 7. Black lines: Cyclic voltammograms of BoX-H at different concentrations (top : $3.510^{-3} \mathrm{M}$; bottom : $3.510^{-4} \mathrm{M}$ ) and at different scan rates (left : $50 \mathrm{mV} . \mathrm{s}^{-1}$; middle : $200 \mathrm{mV} . \mathrm{s}^{-1}$; right : $1000 \mathrm{mV} . \mathrm{s}^{-1}$ ) in $0.1 \mathrm{M}$ $\mathrm{TBAPF}_{6} / \mathrm{CH}_{3} \mathrm{CN}$ on glassy carbon electrode. Note that the baselines were subtracted on CVs. Red shortshort line: electrochemical simulations performed from experiments: $E_{1}^{0}=0.64 \mathrm{~V}, E^{0}{ }_{2}=0.39 \mathrm{~V}, \mathrm{k}_{\mathrm{f} 1}=0.7 \mathrm{~s}^{-1}$, $\mathrm{k}_{\mathrm{f} 2}=410^{5} \mathrm{M}^{-1} \mathrm{~s}^{-1}, \mathrm{k}_{\mathrm{f} 3}=110^{4} \mathrm{~s}^{-1}, \alpha=0.5, \mathrm{D}=10^{-5} \mathrm{~cm}^{2} \cdot \mathrm{s}^{-1}$ and $\mathrm{k}_{\mathrm{s}}=0.01 \mathrm{~cm} \cdot \mathrm{s}^{-1}$. Simulated CVs were calculated with an approximate simulation based on scheme 3 . 


\section{而每angerers \\ FACULTÉ \\ DES SCIENCES \\ Unité de formation \\ et de recherche \\ MQLTECH}

\section{Dr. Olivier ALEVEQUE}

Phone $\quad(+33)(0) 241735090$

Fax (+33) (0)241735405

Email_olivier.aleveque@univ-angers.fr
Professor J.M. FELIU

Depto. de Quimica Fisica, Universidad de Alicante,

Campus de Sant Vicent del Raspeig, 03080, Alicante,

Spain

Angers, March $24^{\text {th }}, 2015$

Highlights

- Original strategy to modulate the electrochemical properties of the indolino[2,1-b]oxazolidine core.

- Study of the stepwise oxidation via cyclic voltammetry and spectroelectrochemistry.

- Confirmation of oxidation process by electrochemical simulations. 